\title{
Lethal and sublethal effects of several plant compounds compared to spiromesifen against Tetranychus turkestani
}

\author{
F. Sohrabi ${ }^{* *}$ and M. Ziaee ${ }^{2}$
}

Summary Tetranychus turkestani Ugarov and Nikolski is one of the main agricultural pests of southwestern Iran and some other tropical regions. In the present study, fumigant activity of three essential oils extracted from Rosmarinus officinalis L., Mentha longifolia L. and Eucalyptus globulus Labill., and contact toxicity of two biopesticides (Tondexir and Palizin) on T. turkestani mite females were investigated and compared with that of spiromesifen, a chemical acaricide. Also, sublethal effects of the tested compounds at $50 \%$ lethal concentration $\left(\mathrm{LC}_{50}\right)$ were estimated on the biological parameters of $T$. turkestani. The $\mathrm{LC}_{50}$ values for $E$. globulus, $R$. officinalis and $M$. longifolia essential oils were 12.50, 11.52 and $4.00 \mu \mathrm{l} / \mathrm{l}$ air and for spiromesifen, Tondexir and Palizin were 10.98, 327.34 and $858.13 \mathrm{ppm}$, respectively. All tested compounds significantly reduced adult female longevity, equally to the chemical acaricide spiromesifen. Fecundity also decreased in all treatments and this reduction was even higher for plant essential oils than the other compounds. Palizin, E. globulus and M. longifolia significantly reduced the hatchability of T. turkestani eggs similarly to spiromesifen. According to the results, the tested plant compounds are effective against T. turkestani and may be applied as suitable alternatives to synthetic pesticides against this crop pest.

Additional keywords: biological parameters, biopesticide, Palizin, spider mite, Tondexir

\section{Introduction}

Tetranychus turkestani Ugarov and Nikolski, strawberry spider mite, (Acari: Tetranychidae) is a severe pest in some parts of tropical regions and southwestern Iran (Zhang, 2003; Karami-Jamour and Shishehbor, 2012). It is a polyphagous pest and has been reported from 270 host plants worldwide (Jeppson et al., 1975; Migeon and Dorkeld, 20062013). The mite feeds in a piercing-sucking manner on the underside of leaves, covers leaves by web, thus destroying plant cells and tissue. The feeding causes yellow chlorotic spots on leaves and decreases photosynthetic rate of plants (Martinez-Ferrer et al., 2006; Mohammadi et al., 2015).

In Iran, synthetic acaricides are mainly

\footnotetext{
1 Department of Plant Protection, Faculty of Agriculture, Persian Gulf University, Bushehr, Iran, P.O. Box 75169-13798.

2 Department of Plant Protection, Faculty of Agriculture, Shahid Chamran University of Ahvaz, Ahvaz, Iran.

* Corresponding author: f.sohrabi1361@gmail.com fsohrabi@pgu.ac.ir
}

applied against spider mites in various crops (Nikpay et al., 2016; Morteza et al., 2017; Ziaee et al., 2017). However, high propagation potential, short generation time, and arrhenotokous parthenogenesis, combined with repeated acaricide use, led to the build-up of resistance among mite populations. Finding alternative control methods that are sustainable and environmentally friendly is necessary (Lee et al., 2003; Van Leeuwen et al., 2005; Pree et al., 2005; Osakabe et al., 2009).

Plant essential oils can be considered as an alternative for controlling spider mites, due to their compatibility with biological control agents and shorter residual effect, while they are safer to humans (Chiasson et al., 2004; Hincapié et al., 2008; Hussein et al, 2013). As a result, the application of botanical pesticides and their natural compounds has been considered for pest control in recent years (Isman, 2000). Rosmarinus officinalis L., Mentha longifolia L. (both Lamiaceae) and Eucalyptus globulus Labill. (Myrtaceae) are considered as three of the most valuable aromatic and medicinal plants. The lethal and sublethal impact of essential oils extracted 
from these plants have been demonstrated on tetranychid mites in the past. Miresmailli et al. (2006) and Choi et al. (2004) pointed out that $R$. officinalis essential oils was effective against the phytophagous mite Tetranychus urticae Koch. Motazedian et al. (2012) stated that the essential oil of $M$. longifolia possesses a repellent effect against $T$. urticae. The results of repellent, antifeedent and toxic effects of E. globulus essential oil on $T$. urticae showed that E. globulus essential oil can be considered as a natural agent against T. urticae (Hussein et al., 2013).

Botanical pesticides have also been reported as a source of bioacaricides for the control of tetranychid mites (Azaizeh et al., 2007; Nikpay et al., 2016). Tondexir contains pepper extract (TON) and Palizin is coconut extract (PAL). They are two botanical pesticides recently used in Iran against various pests, including spider mites (Kabiri et al., 2013; Honarmand et al., 2016; Mirfakhraie and Mohamadian, 2017; Sohrabi et al., 2019).

Evaluation of lethal and sublethal effects of any pesticide on spider mites is essential for assessing the toxicity of the pesticide and probability of resistance development in the mite population (Stark and Banks, 2003; Mohammadi et al., 2016). Therefore, in this study, the lethal and sublethal effects of several plant compounds including $R$. officinalis, M. longifolia, and E. globulus essential oils and two biopesticides (Tondexir and Palizin) were evaluated against $T$. turkestani females and compared with that of Spiromesifen, a commercial chemical acaricide.

\section{Materials and Methods}

\section{Mite culture}

Tetranychus turkestani population used for the bioassays was reared in the laboratory on cowpea, Vigna unguiculata (L.) Walp. at $27 \pm 1^{\circ} \mathrm{C}, 65 \pm 5 \%$ R.H. and a $16: 8 \mathrm{~L}: D$ photoperiod.

\section{Test compounds}

Rosmarinus officinalis, $M$. longifolia, and E. globulus essential oils of $100 \%$ puri- ty were tested which were provided by the Essential Herbal Pharmaceutical Company (Golestan, Iran). The bioacaricides used were Palizin SL 65\% (PAL) and Tondexir EC 85\% (TON), provided by Kimia Sabzavar Co., Iran. Spiromesifen, as commercial formulation Oberon ${ }^{\circledR}$ (SC 24\%; Bayer CropScience), was purchased from Giah Bazr Alvand Company, Iran.

\section{Bioassay tests}

Fumigant toxicity of $R$. officinalis, M. longifolia, and E. globulus essential oils on adult females of T. turkestani.

The fumigant toxicity of the essential oils was assessed in plastic Petri dishes $(6 \mathrm{~cm}$ diameter, which offers $75 \mathrm{ml}$ air space). Leaf discs of bean plants ( $3 \mathrm{~cm}$ in diameter) were placed with their dorsal side inside the Petri dishes on wet cotton. Ten adult females of mite were separately placed on the leaf plant discs using a soft paintbrush. Filter paper disks (Whatman No. $1,2 \mathrm{~cm}$ in diameter) were treated with concentrations of the essential oils and placed in the Petri dishes. Five concentrations containing 1.33, 6.67, 13.33, $33.33,66.67 \mu \mathrm{l} / \mathrm{I}$ air of $R$. officinalis and $E$. globulus, and $0.13,1.33,6.67,13.33,26.67 \mu \mathrm{l} / \mathrm{I}$ air of $M$. longifolia were used for the experiments with three replications, based on preliminary experiments and acetone was applied as a solvent. The caps of the Petri dishes were covered with parafilm to hinder the release of essential oils. In the control, filter papers were treated with acetone alone. The mortality was estimated using a stereomicroscope after $24 \mathrm{~h}$ of exposure. Mites were considered as dead, when no reaction was observed after fine paintbrush stimulation. The bioassays were conducted at $27 \pm 1^{\circ} \mathrm{C}, 65 \pm 5 \%$ R.H. and a 16:8 L:D photoperiod.

Contact toxicity of Tondexir, Palizin, and spiromesifen acaridides against adult females of T. turkestani

Based on preliminary experiments, five concentrations containing 200, 320, 500, 900, 1500 ppm for TON and 100, 250, 500, 1000, 2500 ppm for PAL, and 10, 100, 250, 
$500,1000 \mathrm{ppm}$ in case of spiromesifen were used against the adult females of mites. Leaf discs of bean ( $3 \mathrm{~cm}$ diameter) were immersed in acaricide concentrations for 10 seconds and distilled water served as the control treatment. They were subsequently dried at room temperature for $30 \mathrm{~min}$, then transferred in Petri dishes $(6 \mathrm{~cm}$ in diameter) on wet cotton. Three replications were used for each concentration. Then, ten adult females were introduced into each Petri dish, ventilated through a hole of $1-\mathrm{cm}$ diameter that was covered with organza net. Experiments were conducted at $27 \pm 1^{\circ} \mathrm{C}, 65 \pm 5 \%$ R.H. and a photoperiod of 16:8 L:D in a growth chamber. Mortality was determined under a stereomicroscope after $24 \mathrm{~h}$ of exposure.

\section{Sublethal effects}

Sublethal effects of the six tested compounds at $50 \%$ lethal concentration $\left(\mathrm{LC}_{50}\right)$ on biological parameters of T. turkestani, including adult longevity, fecundity and hatchability were studied. About 100 adult females ( $<24 \mathrm{~h}$ old) were exposed to $L C_{50}$ of each essential oil $(12.50,11.52$ and $4.00 \mu \mathrm{l} / \mathrm{l}$ for E. globulus, $R$. officinalis, and M. longifolia, respectively) and acaricide (10.98, 327.34 and 858.13 ppm for spiromesifen, TON and PAL, respectively) using the bioassays described above. Untreated mites were used as control. After $24 \mathrm{~h}, 20$ alive T. turkestani females were randomly selected for each treatment and transferred individually to new untreated leaves inside Petri dishes on water-soaked cotton. Leaf discs were provided daily for each female mite (Li et al., 2017). Then the adult longevity, oviposition and egg hatch were estimated. To study each compound's sublethal effects on the hatching rate, 30 eggs in six replicates were randomly selected and incubated under the conditions described above for hatching. Experiments were conducted at $27 \pm 1^{\circ} \mathrm{C}, 65 \pm 5 \%$ R.H. and a photoperiod of $16: 8 \mathrm{~L}: \mathrm{D}$ in a growth chamber.

\section{Data analysis}

Lethal concentration value $\left(\mathrm{LC}_{50}\right)$ and its corresponding 95\% fiducial limits (FL) for each essential oil and pesticides were esti- mated using Polo-PC software. Lethal concentration ratios were performed to estimate the compounds' relative potency as described by Robertson et al. (2007). The log- probity curves were created using Microsoft Excel 2007. Data from the sublethal bioassays were analyzed using analysis of variance (ANOVA). The Duncan's Multiple Range Test separated means at 0.05 probability (SAS Institute, 2003). The percentage data were transformed to the square root of arcsine, and longevity data were transformed to square-root, before analysis.

\section{Results}

\section{Fumigant toxicity of essential oils}

The toxicity of essential oils on T. turkestani adults $24 \mathrm{~h}$ after exposure significantly increased with increasing concentrations (for E. globulus: $\mathrm{F}=14.69$; d.f. $=4,10 ; \mathrm{p}=$ 0.0003; R. officinalis: $\mathrm{F}=22.71 ;$ d.f. $=4,10 ; \mathrm{p}$ $<.0001$; and for M. longifolia: $F=5.68$; d.f. $=$ 4,$10 ; p=0.0119$ ) (Figure 1). $L C_{50}$ values of the tested essential oils are presented in Table 1. According to the $\mathrm{LC}_{50}$ values, $M$. longifolia was more effective than E. globulus and $R$. officinalis against $T$. turkestani adults (Table 1).

\section{Contact toxicity of bioacaricides}

The toxicity of acaricides significantly increased when T. turkestani adults were exposed to increasing concentrations of the tested compounds for $24 \mathrm{~h}$ (for Tondexir: $\mathrm{F}=$ 12.98; d.f. $=4,10 ; p=0.0006$; Palizin: $F=5.58$; d.f. $=4,10 ; p=0.0126$; and for Spiromesifen: $F=35.50 ;$ d.f. $=4,10 ; p<.0001$ ) (Figure 2). The $\mathrm{LC}_{50}$ values of the three acaricides tested are presented in Table 2. These values and the confidence limits of toxicity ratios revealed that these acaricides' toxicity was significantly different for T. turkestani adults. The chemical acaricide Spiromesifen was significantly more effective than the two bioacaricides Tondexir and Palizin against T. turkestani adults (Table 2).

\section{Sublethal effects}

The sublethal effects of different com- 


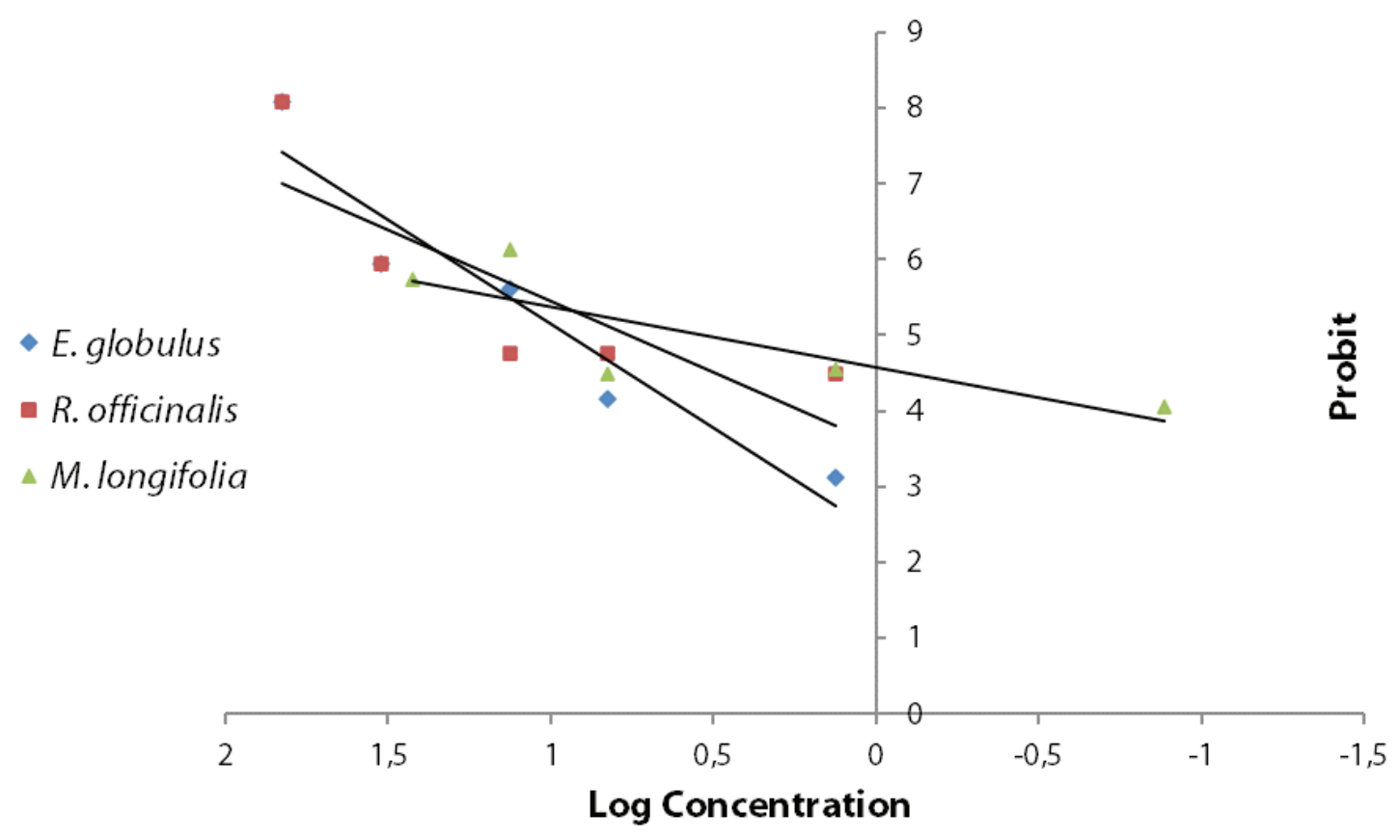

Figure 1. Log- Probity curve of plant essential oils of Eucalyptus globulus, Rosmarinus officinalis and Mentha longifolia on the strawberry spider mite Tetranychus turkestani.

Table 1. Probit analysis and lethal concentration ratios (\% 95 fiducial limits) of Eucalyptus globulus, Rosmarinus officinalis and Mentha longifolia essential oils against the adult females of Tetranychus turkestani.

\begin{tabular}{l|c|c|c}
\hline \multirow{2}{*}{ Parameters } & \multicolumn{3}{|c}{ Essential oil } \\
& E. globulus & M. longifolia & R. officinalis \\
\hline Slope $\pm \mathrm{SE}$ & $3.01 \pm 0.71$ & $0.79 \pm 0.27$ & $1.82 \pm 0.60$ \\
$\mathrm{LC}_{50}(95 \% \mathrm{FL})(\mu \mathrm{l} / \mathrm{l}$ air $)$ & 12.50 & 4.00 & 11.52 \\
& $(1.40-30.12)$ & $(0.54-29.64)$ & $(3.87-16.73)$ \\
$\mathrm{X}^{2}(\mathrm{df}=3)$ & 8.04 & 15.36 & 13.45 \\
$\mathrm{RP}^{\mathrm{a}}$ & - & 0.572 & - \\
& - & $(0.313-1.044)$ & 1.005 \\
$\mathrm{RPb}$ & - & - & $(0.606-1.665)$ \\
& - & - & 1.757 \\
$\mathrm{RPc}$ & & & $(0.871-3.541)$ \\
\hline
\end{tabular}

a Relative potency for $\mathrm{LC}_{50}$ of $M$. longifolia/ E. globulus

${ }^{b}$ Relative potency for $\mathrm{LC}_{50}$ of $R$. officinalis/ E. globulus

c Relative potency for $\mathrm{LC}_{50}$ of $R$. officinalis/ M. longifolia

pounds on biological parameters of T. turkestani adults are shown in Table 3. All tested compounds significantly reduced the fecundity $(F=58.76 ; d f=6,133 ; P<0.0001)$ and longevity $(F=7.37 ; \mathrm{df}=6,133 ; \mathrm{P}<0.0001)$ of the treated females compared with the control. The reduction in the number of eggs was significantly greater in the female mites treated with the essential oils $E$. globulus, M. longifolia and $R$. officinalis than 


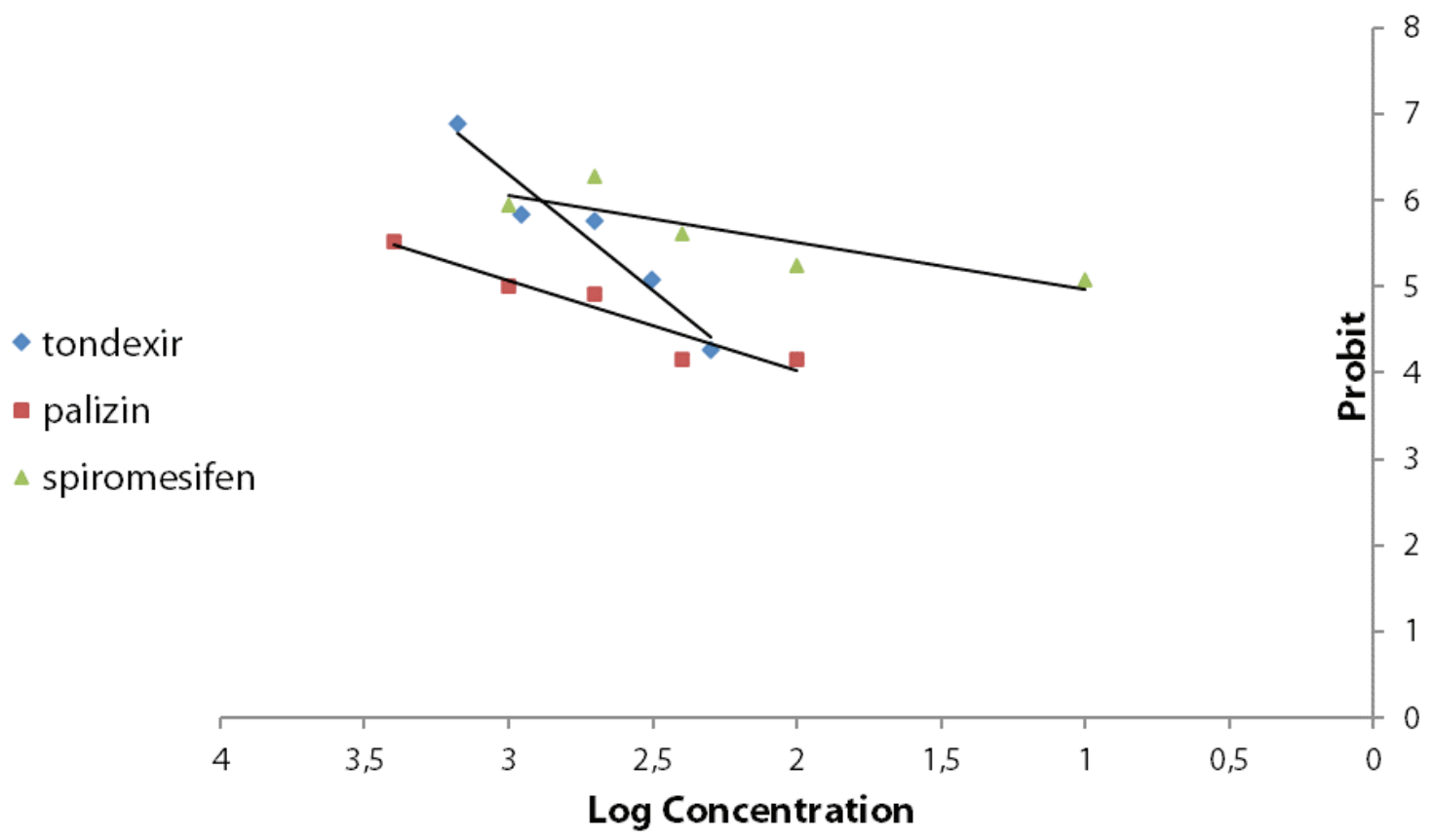

Figure 2. Log- Probity curve of three acaricides (Tondexir, Palizin, spiramesifen) on the strawberry spider mite Tetranychus turkestani.

Table 2. Probit analysis and lethal concentration ratios (\% 95 fiducial limits) of Tondexir, Palizin and spiromesifen against the adult females of Tetranychus turkestani.

\begin{tabular}{|c|c|c|c|}
\hline \multirow{2}{*}{ Parameters } & \multicolumn{3}{|c|}{ Compound } \\
\hline & Tondexir & Palizin & spiromesifen \\
\hline Slope \pm SE & $2.60 \pm 0.43$ & $1.04 \pm 0.23$ & $0.52 \pm 0.16$ \\
\hline $\mathrm{LC}_{50}(95 \% \mathrm{FL})(\mathrm{ppm})$ & $\begin{array}{c}327.34 \\
(248.02-402.91)\end{array}$ & $\begin{array}{c}858.13 \\
(538.85-1689)\end{array}$ & $\begin{array}{c}10.98 \\
(0.23-37.20)\end{array}$ \\
\hline$x^{2}(d f=3)$ & 3.14 & 2.02 & 3.24 \\
\hline $\mathrm{RP}^{\mathrm{a}}$ & - & $\begin{array}{c}3.143 \\
(1.798-5.494)\end{array}$ & - \\
\hline $\mathrm{RP}^{\mathrm{b}}$ & - & - & $\begin{array}{c}0.030 \\
(0.005-0.177)\end{array}$ \\
\hline $\mathrm{RP}^{\mathrm{c}}$ & - & - & $\begin{array}{c}0.010 \\
(0.002-0.060)\end{array}$ \\
\hline
\end{tabular}

a Relative potency for $\mathrm{LC}_{50}$ of Palizin/Tondexir

${ }^{b}$ Relative potency for $\mathrm{LC}_{50}$ of spiromesifen/Tondexir

c Relative potency for $\mathrm{LC}_{50}$ of spiromesifen/Palizin

in females treated with the chemical acaricide spiromesifen. No significant difference was observed in longevity between the females treated with spiromesifen and the females treated with tested plant compounds. The percentage of egg hatchability was also significantly affected by the treatments ( $F$ $=3.34 ; \mathrm{df}=6,35 ; \mathrm{P}=0.0104)$. Compared with the control, the females treated with spiromesifen and three plant compounds, Palizin, E. globulus and M. longifolia had significantly lowered hatchability (Table 3). 
Table 3. Sublethal effects of different compounds on Tetranychus turkestani adults (Mean \pm $\mathrm{SE})^{\mathrm{a}}$.

\begin{tabular}{l|c|c|c}
\hline \multicolumn{1}{l}{ Treatment } & $\begin{array}{c}\text { Number of eggs } \\
\text { perfemale }\end{array}$ & \% Egg hatch & $\begin{array}{c}\text { Female longevity } \\
\text { (days) }\end{array}$ \\
\hline Control & $20.15 \pm 1.27 \mathrm{a}$ & $100.00 \pm 0.00 \mathrm{a}$ & $15.95 \pm 0.68 \mathrm{a}$ \\
Tondexir & $16.10 \pm 0.64 \mathrm{bc}$ & $82.33 \pm 11.20 \mathrm{abc}$ & $10.45 \pm 0.84 \mathrm{bc}$ \\
Palizin & $17.2 \pm 0.70 \mathrm{~b}$ & $78.66 \pm 5.89 \mathrm{bc}$ & $12.05 \pm 0.95 \mathrm{~b}$ \\
Spiromesifen & $13.90 \pm 0.46 \mathrm{c}$ & $72.16 \pm 6.60 \mathrm{c}$ & $10.30 \pm 1.05 \mathrm{bc}$ \\
Eucalyptus globulus & $10.3 \pm 1.13 \mathrm{~d}$ & $77.83 \pm 5.64 \mathrm{bc}$ & $11.35 \pm 1.00 \mathrm{~b}$ \\
Mentha longifolia & $1.2 \pm 0.09 \mathrm{e}$ & $79.28 \pm 0.32 \mathrm{bc}$ & $7.90 \pm 0.69 \mathrm{c}$ \\
Rosmarinus officinalis & $8.80 \pm 0.88 \mathrm{~d}$ & $88.83 \pm 11.16 \mathrm{ab}$ & $9.70 \pm 1.02 \mathrm{bc}$ \\
\hline
\end{tabular}

a Means in each column followed by the same letter were not significantly different at the 0.05 level when tested by Duncan's Multiple Range Test.

\section{Discussion}

Essential oils are phytochemicals with repellent and toxic properties against mites (Cavalcanti et al., 2010; Sertkaya et al., 2010; Attia et al., 2012; Camilo et al., 2017). Our results clearly showed that essential oils from the aromatic plants $R$. officinalis, M. longifolia, and E. globulus possess acaricidal activity against $T$. turkestani adults. The fumigant toxicity of $M$. longifolia was higher than that of E. globulus and R. officinalis. Furthermore, mite mortality increased with essential oil concentration. As shown in a previous study, the essential oil of $M$. longifolia is active against T. urticae with an $\mathrm{LC}_{50}$ value of 20.08 $\mu \mathrm{l} / \mathrm{l}$ air (Motazedian et al., 2012). Aissaoui et al. (2019) reported substantial contact toxicity of E. globulus essential oil against different stages of $T$. urticae and a continuous increase in mortality rates of spider mite larvae and adults was observed with increasing concentration. In another study, Hussein et al. (2013) examined the contact activity of three plant essential oils, including that of $E$. globulus against females of T. urticae. They found that E. globulus essential oil is effective with an $L C_{50}$ value of $2.202 \%$. Efficacy of rosemary oil when applied as an acaricide to control two-spotted spider mite has been reported in previous studies (Miresmailli \& Isman, 2006; Miresmailli et al. 2006). In the study conducted by Choi et al. (2004), rosemary oil was not acutely toxic (mortality $<60 \%$ ) against $T$. urticae compared with oil of eucalyptus.

Spiromesifen is one of the most promising chemical acaricides for managing spider mites. It is an acetyl-CoA-carboxylase inhibitor, a lipid metabolism enzyme (Kontsedalov et al., 2009; Sato et al., 2011; Reddy \& Latha, 2013). Our results suggested that spiromesifen was the most toxic acaricide to adult mites with an $\mathrm{LC}_{50}$ value of $10.98 \mathrm{ppm}$, which was lower than the $\mathrm{LC}_{50}(12.53 \mathrm{ppm})$ reported by Kumari et al. (2017) against T. urticae. Based on our results, the bioacaricides TON and PAL were toxic to adult mites. Antonious et al. (2007) indicated that the pesticide TON has lethal effects on T. urticae, which could be attributed to pepper extract as an active agent in this formulation. Our results also indicate that PAL was the least toxic $\left(\mathrm{LC}_{50}=858.13 \mathrm{ppm}\right)$ against $T$. turkestani, i.e. 78 times less effective than spiromesifen. In another study, Mirfakhraie and Mohamadian (2017) reported the repellency effect of PAL and contact toxicity of TON against females of $T$. urticae with an $L_{50}$ value of 2130.91 ppm.

Our findings revealed that all the compounds at $\mathrm{LC}_{50}$ significantly affected $T$. turkestani females' biological parameters compared to control. The chemical acaricide spiromesifen and all three plant compounds caused adverse effects on T. turkestani fe- 
males' longevity. Reduced female longevity led to a reduction in reproductive capacity. The highest significant decrease in fecundity rate by $94 \%$ was observed after exposing newly emerged adults to $M$. longifolia essential oil. Similarly to our results, Momen et al. (2018) reported the great potential of $M$. longifolia to deterrent the oviposition of T. urticae by $99.4 \%$ decrease in egg production. In the study conducted by Mohamed et al. (2015), the extract of M. longifolia reduced T. urticae female longevity and ovipositional period and the total number of laid eggs. Furthermore, sublethal effects of plant essential oils on the fecundity and fertility of spider mites have been reported in the previous studies (Momen et al., 2001; Lim et al., 2011; Abd El-Moneim et al., 2012; Gholamzadeh-Chitgar et al., 2013; Esmaeily et al., 2017).

Hatchability of $T$. turkestani eggs was also significantly reduced by spiromesifen and some plant compounds tested, including PAL, E. globulus and M. longifolia. However, TON and $R$. officinalis did not significantly affect the percentage of eggs hatched. Similarly, Ismail et al. (2011) reported that $R$. officinalis oil did not affect two-spotted spider female fertility. There are no other studies concerning the impact of TON and PAL on biological parameters of spider mites to the best of our knowledge. The chemical acaricide spiromesifen also reduced the fecundity and egg hatchability of T. turkestani to 31 and $28 \%$, respectively. Similarly, Nauen et al. (2005) found that spiromesifen significantly reduced the fecundity of two-spotted spider mite females at the concentrations between 0.064 and 40 mg/l Marcic et al. (2009) also reported that the number of laid eggs and egg hatchability of T. urticae was significantly affected by $180 \mathrm{mg} / \mathrm{l}, 18 \mathrm{mg} / \mathrm{l}$, and 1.8 $\mathrm{mg} / \mathrm{l}$ concentrations of spiromesifen.

In summary, the present study showed that M. longifolia, E. globulus and R. officinalis essential oils and two bioacaricides (TON and PAL) had satisfactory effects against $T$. turkestani even at a low concentration level. Given the above results and the environmentally friendly properties of plant com- pounds, along with their low persistence in nature and low risk for humans and mammals, these compounds can be considered as reduced-risk pesticides and useful alternatives to synthetic chemicals for spider mite control. These laboratory findings need to be confirmed with further trials to investigate this bioinsecticide' sublethal effect on field populations of this pest. Furthermore, it is critical to test the safety of these compounds before practical use in T. turkestani control in commercial greenhouses.

\section{Literature Cited}

Abd El-Moneim, M.A., Fatma, S.A. and Turky, A.F. 2012. Control of Tetranychus urticae Koch by extracts of three essential oils of chamomile, marjoram and Eucalyptus. Asian Pacific Journal of Tropical Biomedicine, 2(1): 24-30.

Aissaoui, A.B., Zantar, S. and Elamrani, A. 2019. Chemical composition and potential acaricide of Salvia officinalis and Eucalyptus globulus on Tetranychus urticae Koch (Acarina: Tetranychidae). Journal of Applied Chemistry and Environment Protection, 4(1): 280-292.

Antonious, G.F., Meyer, J.E., Rogers, J.A. and Hu, Y.H. 2007. Growing hot pepper for cabbage looper, Trichopulsia ni (Hubner) and spider mite, Tetranychus urticae (Koch) control. Journal of Environmental Science and Health, 42(5): 559-567.

Attia, S., Grissa, K.L., Mailleux, A.C., Heuskin, S., Lognay, G. and Hance, T. 2012. Acaricidal activities of Santolina africana and Hertia cheirifolia essential oils against the two-spotted spider mite (Tetranychus urticae). Pest Management Science, 68(7): 1069-1076.

Azaizeh, H., Kobaisy, M., Dakwar, S., Saad, B., Shaqir, I. and Said, O. 2007. Botanical pesticides as a source of safe bioacaricides for the control of Tetranychus cinnabarinus. Acta Phytopathologica et Entomologica Hungarica, 42(1): 143-152.

Camilo, C.J., Alves Nonato, C.D.F., Galvão-Rodrigues, F.F., Costa, W.D., Clemente, G.G., Sobreira Macedo, M.A.C., Galvão Rodrigues, F.F. and Da Costa, J.G.M. 2017. Acaricidal activity of essential oils: a review. Trends in Phytochemical Research, 1(4): 183-198.

Cavalcanti, S.C.H., Niculau, E.S., Blank, A.F., Câmara, C.A.G., Araújo, I.N. and Alves, P.B. 2010. Composition and acaricidal activity of Lippia sidoides essential oil against two-spotted spider mite (Tetranychus urticae Koch). Bioresourse Technology, 101(2): 829-832.

Choi, W.I., Lee, S.G., Park, H.M. and Ahn, Y.J. 2004. Toxicity of plant essential oils to Tetranychus ur- 
ticae (Acari: Tetranychidae) and Phytoseiulus persimilis (Acari: Phytoseiidae). Journal of Economic Entomology, 97: 553-558.

Chiasson, H., Bostanian, N.J. and Vincent, C. 2004. Acaricidal properties of a Chenopodium-based botanical. Journal of Economic Entomology, 97(4): 1373-1377.

Esmaeily, M., Bandani, A., Zibaee, I. and Sharifian, I. 2017. Sublethal effects of Artemisia annua L. and Rosmarinus officinalis L. essential oils on life table parameters of Tetranychus urticae (Acari: Tetranychidae). Persian Journal of Acarology, 6(1): 39-52.

Gholamzadeh-Chitgar, M., Khosravi, R., JalaliSendi, J. and Ghadamyari, M. 2013. Sublethal effects of Thymus vulgaris essential oil on life-table parameters of two-spotted spider mite, Tetranychus urticae Koch (Acari: Tetranychidae). Archives of Phytopathology and Plant Protection, 46: 781-788.

Hincapié, C.A., López, G.E. and Torres, R. 2008. Comparison and characterization of garlic (Allium sativum L.) bulbs extracts and their effect on mortality and repellency of Tetranychus urticae Koch (Acari: Tetranychidae). Chilean Journal of Agricultural Research, 68(4): 317-327.

Honarmand, P., Nouri, G., Dastjerdi, H.R., Hassanpour, M. and Fathi, S.A.A. 2016. Lethal effect of three synthetic insecticides and two commercial botanical extracts on the Sunn pest, Eurygaster integriceps Puton under the field and laboratory conditions. Plant Pest Research, 6(3): 65-77.

Hussein, H., Reda, A. and Momen, F. 2013. Repellent, antifeedent and toxic effects of three essential oils on the two spotted spider mite, Tetranychus urticae Koch (Acari: Tetranychidae). Acta Phytopathologica et Entomologica Hungarica, 48(1): 177-186.

Isman, M.B. 2000. Plant essential oils for pest and disease management. Crop Protection, 19: 603608.

Ismail, M.S., Ghallab, M., Soliman, M.F. and AboGhalia, A.H. 2011. Acaricidal activities of some essential and fixed oils on the two-spotted spider mite, Tetranychus urticae. Egyptian Academic Journal of Biological Sciences, B. Zoology, 3(1): 41-48.

Jeppson, L.R., Keifer, H.H. and Barker, E.W. 1975. Mites injurious to economic plants Berkeley: University of California Press. 614 pp

Kabiri, M., Raeis, A. and Amiri-Besheli, B. 2013. Comparison of the toxicity of three botanical insecticides and two chemical insecticides on $\mathrm{Ag}$ onoscena pistaciae Burckhardt and Lauterer (Hemiptera: Psyllidae) in laboratory and field conditions. Journal of Agriculture and Crop Sciences, 5(10): 1074-1079.

Karami-Jamour, T. and Shishehbor, P. 2012. Development and life table parameters of Tetrany- chus turkestani (Acarina, Tetranychidae) at different constant temperatures. Acarologia, 52(2): $113-122$

Kumari, S., Chauhan, U., Kumari, A. and Nadda, G. 2017. Comparative toxicities of novel and conventional acaricides against different stages of Tetranychus urticae Koch (Acarina, Tetranychidae). Journal of the Saudi Society of Agricultural Sciences: 16(2): 191-196.

Kontsedalov, S., Gottlieb, Y., Ishaaya, I., Nauen, R., Horowitz, R. and Ghanim, M. 2009. Toxicity of spiromesifen to the developmental stages of Bemisia tabaci biotype B. Pest Management Science, Formerly Pesticide Science, 65(1): 5-13.

LeOra Software. 1987. POLO-PC, user's guide to probit or logit analysis, LeOra Software Inc., Berkeley, CA.

Lee, Y., Song, M., Ahn, K., Lee, K., Kim, J. and Kim, G. 2003. Monitoring of acaricide resistance in twospotted spider mite (Tetranychus urticae) populations from rose greenhouses in Korea. Journal of Asia-Pacific Entomology, 6: 91-96.

Li, Y.Y., Fan, X., Zhang, G.H., Liu, Y.Q., Chen, H.Q., Liu, H. and Wang, J.J. 2017. Sublethal effects of bifenazate on life history and population parameters of Tetranychus urticae (Acari: Tetranychidae). Systematic and Applied Acarology, 22(1): 148-159.

Lim, E.G., Roh, H.S., Coudron, T.A. and Park, C.G. 2011. Temperature-dependent fumigant activity of essential oils against two spotted spider mite (Acari, Tetranychidae). Journal of economic entomology, 104(2): 414-419.

Marčić, D., Ogurlić, I., Mutavdžić, S. and Perić P. 2009. The effect of spiromesifen on the reproductive potential of Tetranychus urticae Koch (Acari, Tetranychidae). Pesticidi i Fitomedicina, 2(3): 203 209.

Martínez-Ferrer, M.T., Jacas, J.A., Ripollés-Moles, J.L. and Aucejo-Romero, S. 2006. Approaches for sampling the two-spotted spider mite (Acari, Tetranychidae) on clementines in Spain. Journal of Economic Entomology, 99(4): 1490-1499.

Migeon, A. and Dorkeld, F. 2006-2013. Spider Mites Web, a comprehensive database for the Tetranychidae. http,//www.montpellier.inra.fr/CBGP/ pmweb. Last accessed on May 2013.

Miresmailli, S., Bradbury, R. and Isman, M.B. 2006. Comparative toxicity of Rosmarinus officinalis L. essential oil and blends of its major constituents against Tetranychus urticae Koch (Acari, Tetranychidae) on two different host plants. Pest Management Science, formerly Pesticide Science, 62(4): 366-371.

Miresmailli, S. and Isman, M.B. 2006. Efficacy and persistence of rosemary oil as an acaricide against two-spotted spider mite (Acari, Tetranychidae) on greenhouse tomato. Journal of Economic Entomology, 99(6): 2015-2023. 
Mirfakhraie, S. and Mohamadian, P. 2017. Effects of botanical insecticides sirinol, tondexir and repellency of palizin on two spotted spider mite (Tetranychus urticae Koch) in the laboratory conditions. Plant Protection (Scientific Journal of Agriculture), 40(3): 1-12.

Motazedian, N., Ravan, S. and Bandani, A.R. 2012. Toxicity and repellency effects of three essential oils against Tetranychus urticae Koch (Acari, Tetranychidae). Journal of Agricultural Science and Technology, 14: 275-284.

Mohammadi, S., Seraj, A.A. and Rajabpour, A. 2015. Evaluation of six cucumber greenhouse cultivars for resistance to Tetranychus turkestani (Acari, Tetranychidae). Journal of Crop Protection, 4(4): 545-556.

Mohammadi, S., Ziaee, M. and Seraj, A.A. 2016. Sublethal effects of Biomite ${ }^{\circledast}$ on the population growth and life table parameters of Tetranychus turkestani Ugarov and Nikolskii on three cucumber cultivars. Systematic and Applied Acarology, 21(2): 218-226.

Momen, F.M., Amer, S.A.A. and Refaat, A.M. 2001. Repellent and oviposition-deterring activity of rosemary and sweet marjoram on the spider mites Tetranychus urticae and Eutetranychus orientalis (Acari, Tetranychidae). Acta Phytopathologica et Entomologica Hungarica, 36(1-2): 55-164.

Morteza, Z., Mousavi, S.B., Baghestani, M.A. and Aitio, A. 2017. An assessment of agricultural pesticide use in Iran, 2012-2014. Journal of Environmental Health Science and Engineering, 15: 1-10.

Mohamed, F.S., Hoda, E.H. Darwish, Z.E., Amer, S.A., Salama, A.B. and El-Desouky, M.E. 2015. Influence of some extracts from three Lamiaceae plants on toxicity, repellency and some biological aspects of Tetranychus urticae Koch (Acari, Tetranychidae). Egyptian Journal of Biological Pest Control, 25(1): p.255.

Momen, F.M., Abdelkader, M.M. and Fahim, S.F. 2018. Composition, repellent and fumigant toxicity of Mentha longifolia essential oil on Tetranychus urticae and three predatory mites of the family phytoseiidae (Acari, Tetranychidae, Phytoseiidae). Acta Phytopathologica et Entomologica Hungarica, 53(2): 221-232.

Nauen, R., Schnorbach, H.J. and Elbert, A. 2005. The biological profile of spiromesifen (Oberon)-a new tetronic acid insecticide/acaricide. Pflanzenschuz-Nachrichten Bayer, 58: 417-440.

Nikpay, A., Soleyman-Nejadian, E., Goldasteh, S. and Farazmand, H. 2016. Efficacy of Biomite ${ }^{\circledR}$ and GCMite ${ }^{\circledR}$ on Oligonychus Sacchari and its predator Stethorus gilvifrons on sugarcane, preliminary results. International Sugar Journal, 118: 454-458.

Osakabe, M.H., Usegi, R. and Goka, K. 2009. Evolutionary aspects of acaricide-resistance development in spider mites. Psyche: 1-11.
Pree, D.J., Whitty, K.J. and Van Driel, L. 2005. Baseline susceptibility and cross resistances of some new acaricides in the European red mite, Panonychus ulmi. Experimental and Applied Acarology, 37(3-4), p.165.

Reddy, D.S. and Latha, M.P. 2013. Efficacy of certain new acaricides against two spotted spider mite, Tetranychus urticae Koch on ridge gourd. Pest Management in Horticultural Ecosystems, 19(2): 199-202.

Robertson, J.L., Russell, R.M., Preisler, H.K. and Savin, N.E. 2007. Bioassay with Arthropods. Taylor and Francis Group, London.

SAS Institute. 2003. The SAS system for Windows, Release 9.0. SAS, Institute, Cary, NC.

Sato, M.E., Da Silva, M.Z., Raga, A., Cangani, K.G., Veronez, B., and Nicastro, R.L. (2011). Spiromesifen toxicity to the spider mite Tetranychus urticae and selectivity to the predator Neoseiulus californicus. Phytoparasitica, 39(5): p.437.

Sertkaya, E., Kaya, K. and Soylu, S. 2010. Acaricidal activities of the essential oils from several medicinal plants against the carmine spider mite (Tetranychus cinnabarinus Boisd.)(Acarina, Tetranychidae). Industrial Crops and Products, 31(1): 107-112.

Stark, J.D. and Banks, J.E. 2003. Population-level effects of pesticides and other toxicants on arthropods. Annual Review of Entomology, 48: 505-519.

Sohrabi, F., Jamali, F., Morammazi, S., Saber, M. and Kamita, S.G. 2019. Evaluation of the compatibility of entomopathogenic fungi and two botanical insecticides tondexir and palizin for controlling Galleria mellonella L. (Lepidoptera, Pyralidae). Crop Protection, 117: 20-25.

Van Leeuwen, T., Van Pottelberge, S. and Tirry, L. 2005. Comparative acaricide susceptibility and detoxifying enzyme activities in field-collected resistant and susceptible strains of Tetranychus urticae. Pest Management Science, formerly Pesticide Science, 61(5): 499-507.

Zhang, Z.Q. 2003. Mites of greenhouse, Identification, biology and control. CABI International, 256.

Ziaee, M., Nikpay, A., Koohzad-Mohammadi, P., and Behnam-Oskuyee, S. 2017. The toxicity of Biomite $^{\oplus}$, GC-mite ${ }^{\oplus}$, Oberon $^{\oplus}$ and Envidor ${ }^{\oplus}$ acaricides against sugarcane yellow mite, Oligonychus sacchari (Acari, Tetranychidae). Persian Journal of Acarology, 6: 137-141.

Received: 4 September 2020; Accepted: 23 June 2021 


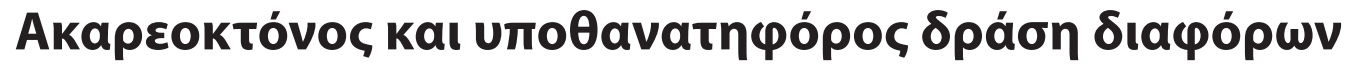

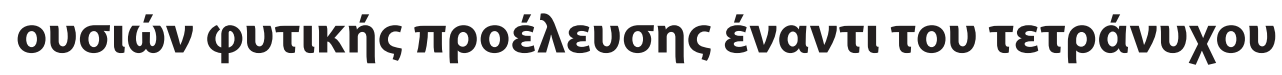

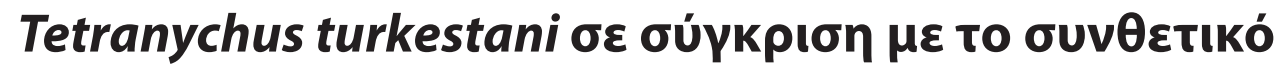 акарєоктóvo spiromesifen}

\section{F. Sohrabi kaı M. Ziaee}

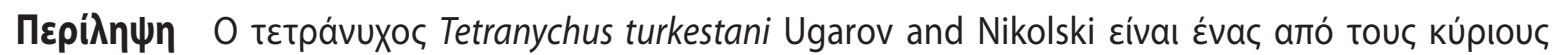

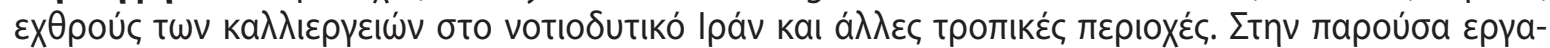

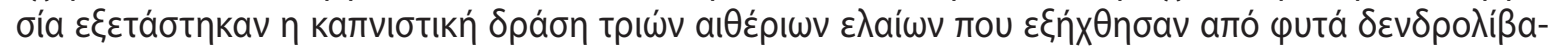

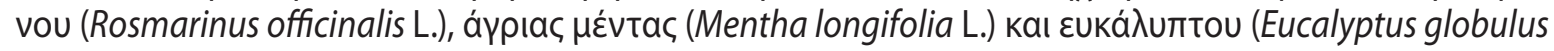

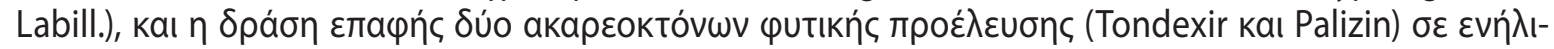

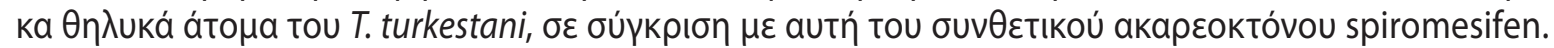

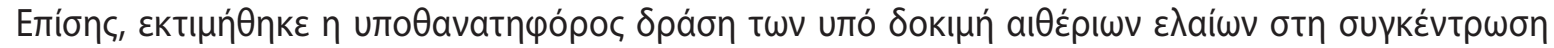

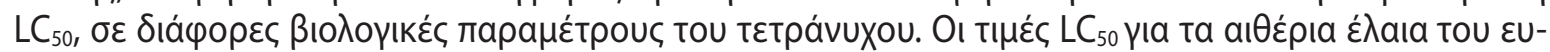

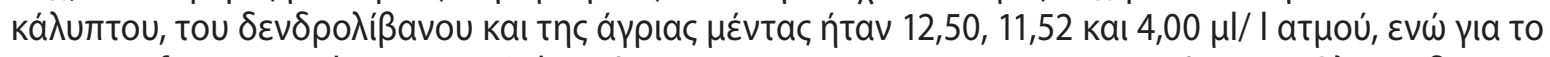

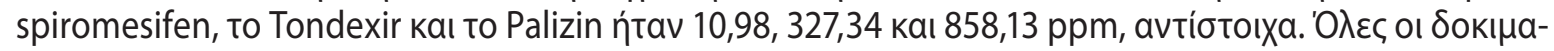

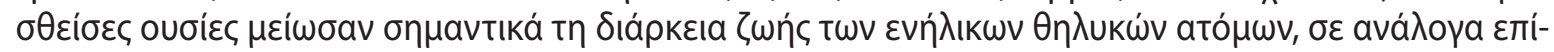

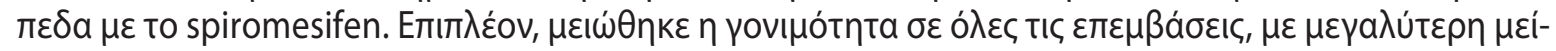

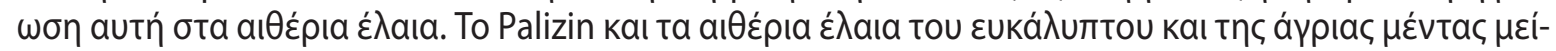

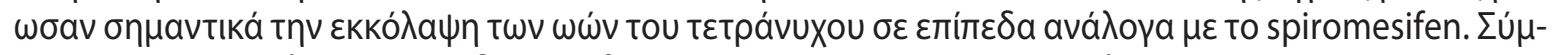

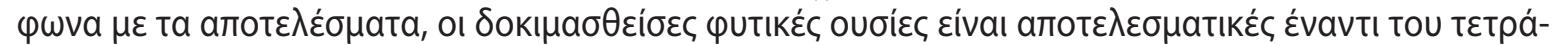

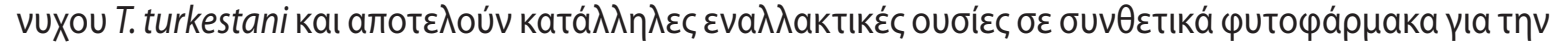

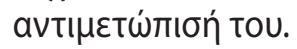

Hellenic Plant Protection Journal 14: 89-98, 2021 